\title{
TIME SERIES ANALYSIS OF THE SKYLINE AND EMPLOYMENT CHANGES IN THE CBD OF MELBOURNE
}

Jun Tsutsumi, Ehime University

Correspondence to Jun Tsutsumi: jtsu@LL.ehime-u.ac.jp

Kevin O'Connor, The University of Melbourne

Correspondence to Kevin O’Connor: kevin.oconnor@unimelb.edu.au

This paper covers historical and micro level analyses of floor space and employment in the CBD of Melbourne during the last two decades. The time-series patterns and processes of high-rise building provision in the CBD are also focused on. The CBD has experienced very complicated changes over the last two decades. While particular types of urban functions, say finance and insurance offices and many retail activities, have been dispersed to the suburbs, newly emerged activities have replaced the old and traditional ones. Despite the growth of suburban cores (office and retail), the CBD of Melbourne has still kept its strong centrality through a role as the main location of office activity in particular. Historical and micro level viewpoints provide a new understanding of the metropolitan area. The key question must be 'Why is the role of the CBD of Melbourne still so strong, given substantial dispersal of population and economic activity to suburban locations?'

\section{INTRODUCTION}

Melbourne is the second largest city after Sydney in the Australian urban system. As many articles argued, the globalization of the economy and the related growth of business service activities, which occurred in the late 1980s and the 1990s, created a strong demand for office spaces in big cities. Sydney received the majority of global investments, while Melbourne ranks second behind Sydney in every category of investment (Hajdu 1994). Thus, in a winner-take-all scenario, Sydney has been a factor limiting growth in Melbourne. There are some other negative factors influenced changes in Melbourne's CBD. Firstly, Melbourne has many suburban office and retail development projects. In fact, within its metropolitan context, until the 1960s, the CBD of Melbourne was the only major centre for retail activities within the entire metropolitan area. At that time, the percentage of retail sales in the CBD was about $47 \%$ within the entire metropolitan area. Since then, the status of the CBD as a retail centre weakened decade by decade, while a number of shopping centres grew in the suburbs. The percentage of retail sales in the CBD dropped to about $12.5 \%$ in 1980 (Brown-May 2005).

Despite these negative factors, many high-rise office buildings have appeared in the Melbourne CBD throughout the last two decades. According to the CLUE database kept by the Melbourne City Council (MCC), the boom in high-rise building construction (over 20 stories) occurred in the 1970s. Generally, $80 \%$ of the total number of current high-rise buildings was constructed after 1970. In addition, according to Tsutsumi and O'connor (2005) and O'Connor (2002; 2004a; 2004b), inner city apartments have become a very significant element in the growth of Melbourne's CBD. In this regard, the remarkable progress of residential development in the CBD has created a new role for the CBD within the Melbourne metropolitan area. 
Gentrification, expressed in inner city residential development, has long been seen as a driving force behind inner area change. This paper proposes that it can also be a major force in CBD development. To create this new perspective the paper uses a geo-temporal measure: the contributions to the skyline change in the CBD of Melbourne. This is a good index of urban growth as it can show the supply of buildings in different parts of the area at different points of time. This time series of construction used change in the pattern of the skyline to provide insight on the change in the underlying urban development. It did that by cross-referencing employment and other socio-economic changes with shifts in the spatial distribution of new buildings.

In this article, the authors focused on the so-called 'city loop area' in the CBD of Melbourne (Figure 1). It covers an area of approximately $2 \mathrm{~km} \times 1 \mathrm{~km}$ ranging from La Trobe Street (north end) to Flinders Street (south end), and from Spencer Street (west end) to Spring Street (east end). The project was designed to take advantage of The City of Melbourne biennial Census of Land Use and Employment (known as the CLUE database), which has been collected for more than 40 years. Socio-economic data from the Australian Bureau of Statistics Census of 2001 were also available to the research while population census data for 1991, 1996 and 2001 were also used.

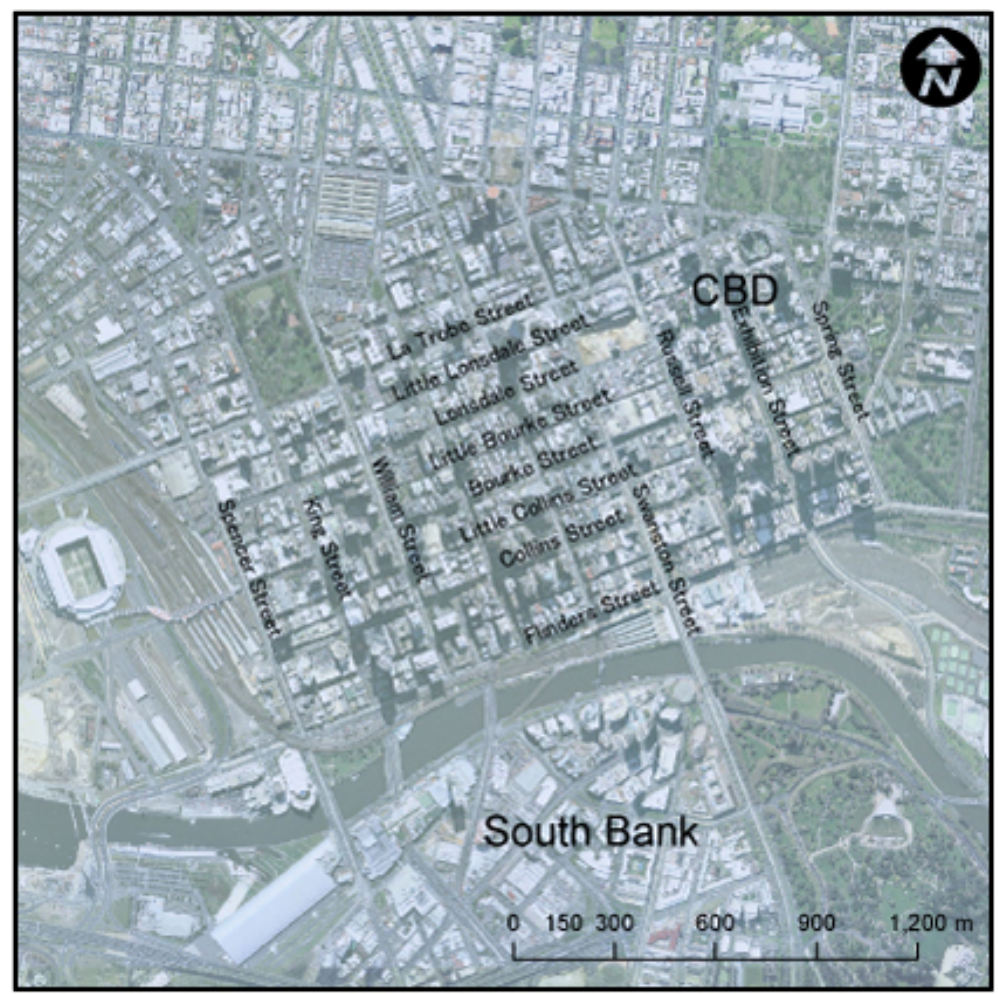

Figure 1 Location map of the study area Vic Map, CLUE Database, Melbourne City Council 


\section{AN OVERVIEW OF HIGH-RISE BUILDING CONSTRUCTION IN THE CBD}

\section{THE CBD ECONOMY; FORCES FOR CHANGE}

There exist some prominent articles describing change in the character of the CBD of Melbourne. Goodman (1983) investigated the CBD of Melbourne at the micro level and identified the nature and forces of city development. In addition, Maher (1988) provided an outstanding description about the growth and urban development process of the city. According to Maher (1988), during the period from the end of the Second World War to the beginning of the 1970s, Melbourne underwent the most sustained growth in its history, especially based on the remarkable progress of manufacturing. At the peak of industrialization in 1966, 37\% of total employment was dedicated to manufacturing, which was much higher than the national average of $27 \%$. In accordance with this growth, a demand for office spaces in Melbourne rapidly increased. Although there was a strong demand for office space, the majority of available office buildings were in the periphery of the CBD due to the shortage of available sites for development. From the mid 1960s and throughout the 1970s, lettable office spaces were mostly provided in the southern area (St. Kilda Road) and the south-western periphery called as Central city fringe (Fothergill 1987).

Structural economic change, such as the substitution of manufacturing activities by serviceproducing activities, has brought the underutilization of industrial sites close to the CBD of Melbourne. This major economic impact can be noticed in two ways in Melbourne: first, redevelopment projects have occurred in the Dockland and Southbank areas which were the heart of former industrial sites; and second, high-rise office developments have taken place in the CBD.

As the globalization of the economy progresses, the driving force of city growth has tended to be limited to a particular category of business: finance, insurance, and real estate (abbreviated as FIRE). Sydney has occupied the first rank and Melbourne the second in the Australian urban system. The economic performance of Melbourne has ranked second behind Sydney in every category of urban indices. However, Melbourne has still been Australia's principal metropolis for major exporting industries (manufacturing, primary industry, and the management of mining) and has attracted some branches of foreign banks and insurance companies. State Government and city council activities occupied approximately $40 \%$ of the total office space in the CBD in 1986; therefore there was little available rental space left over (Fothergill 1987).

This historical experience, along with some City Council land use planning control, laid the basis for two major areas of high rise construction in the CBD, one in the west and one in the east, generally aligned along Collins and Bourke Streets. This pattern leaves a central "valley" around Swanston Street where strict height control guidelines (lower than 40 meters) apply. These relate to concern to preserve many Gothic style buildings and old low-rise brick buildings. Some of them are over a century in age: they were mainly constructed in the prosperous Gold Rush period in the 19th century. Sometimes, they are used as ethnic restaurants and cafes. In this area building refurbishment is a more significant source of quality space for property management than new construction.

\section{LOCATIONAL TRENDS OF BUILDINGS IN THE CBD DURING THE 1980s}

Figure 2 shows the year of construction of each building in the CBD of Melbourne based on the CLUE database obtained from MCC. Orange, pink and red colors in figure 2 denote new 
buildings from 1980 onwards: There are a few redevelopments in the eastern part of Collins Street, while other new buildings have appeared in western and northern parts of the CBD. A construction/ redevelopment boom in high-rise office building can be seen in the western part of Collins Street. The Department of Infrastructure relaxed land use control in the CBD in the mid 1980s, resulting in the construction of new high-rise office buildings in the western and northern parts of the CBD. The Bourke Place building (56 stories), appeared in 1992 in the western part of the CBD, and its creation marked the beginning of a major boom in high-rise construction. Several buildings, most of which were over 50 stories, followed this trend. New buildings were constructed even in the place that used to be the periphery of the CBD. The number of new buildings has caused much vacant land use: among office buildings in the western part of the CBD; the vacancy rate in the early 1990s was very high. After completion of these properties, the distribution of high-rise buildings changed from concentrated to dispersed, which meant that the CBD expanded both horizontally and vertically, throwing off its old two core structure.

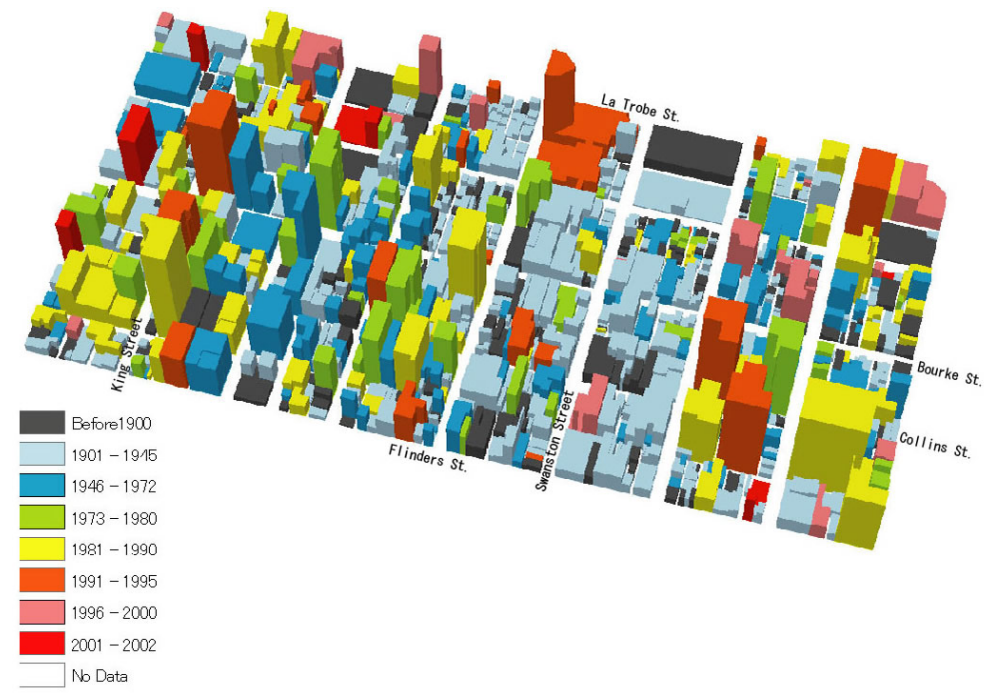

Figure $23 \mathrm{D}$ skyline by built year of buildings in the CBD of Melbourne CLUE Database, Melbourne City Council

Figure 3 confirms that shift in dramatic terms. It shows the distribution pattern of buildings built after 1991 . We can identify many large lot buildings, which extend to several hundreds meters wide, in the western and southern part of the CBD. The Casino building, Exhibition Centre, Federation Square, and Telstra Dome are the most prominent. Within the CBD, the majority of newer buildings still occur along Collins Street in the southern part of the CBD. But we can also identify some high-rise housing in the northern part of the CBD, closer to two big universities. Another trend can be found in the Southbank and Dockland areas where much highrise building has occurred. It would seem the CBD is dispersing in many different directions, seemingly loosing any coherence in its skyline. 


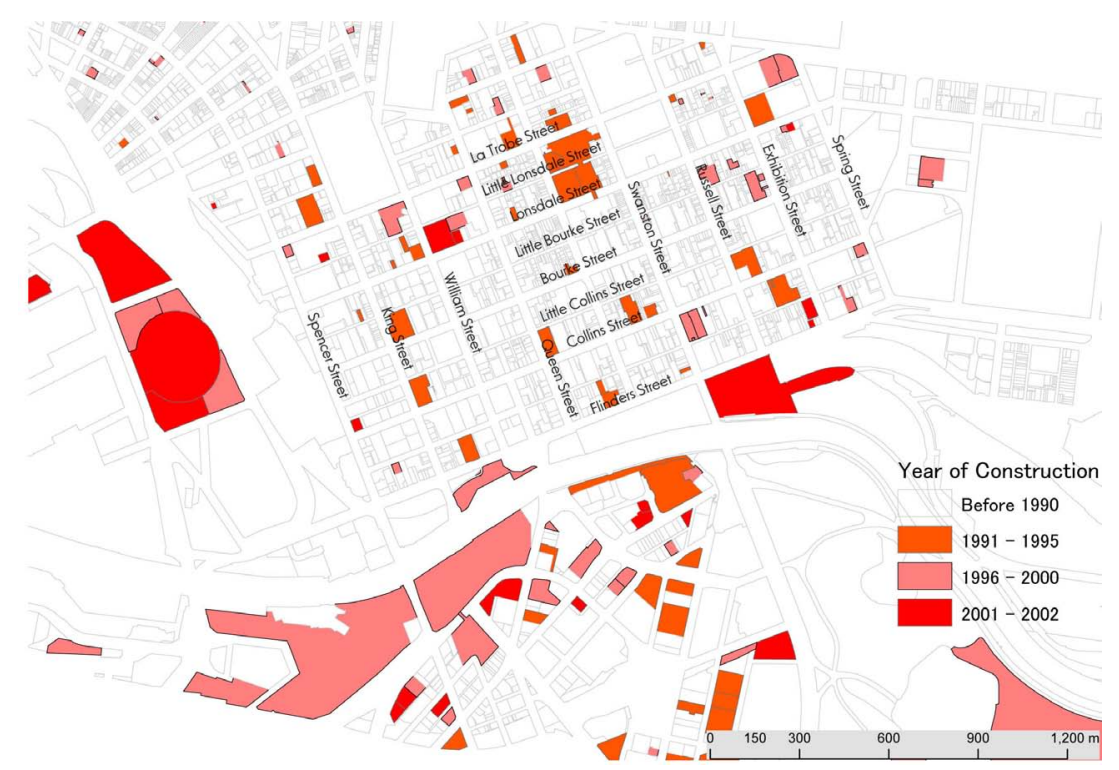

Figure 3 Relatively new buildings built after 1990 in the CBD of Melbourne Vic Map, CLUE Database, Melbourne City Council

At this time too a shift in building style could be discerned. A concern with the heritage value of older buildings is shown in Picture 1, a good illustration of typical Melbourne's architecture. Along the street, the developer has tried to preserve the low-rise old building, responding to the concern with heritage outlined above. Behind these frontages, however, connections are made to new high-rise buildings. The reception facility, lobby and cafes are located in the facade part of the old building. People walking along the street don't realize that there are high-rise buildings behind the old facade. "Over 30 stories”, “very nice”, "prestigious”... are common words used by selling agents for describing these buildings. Recently these kinds of high-rise buildings have become common on many sites in the CBD. These buildings often accommodate high quality business services (lawyers, solicitors, accountings etc.) but also tourism-oriented functions (cafes, retail, hotels etc). The outcome is that newly emerged functions (especially the number of young professionals and tourist-oriented businesses) located in new buildings have begun to replace the old traditional types of activity in the CBD.

However it is likely that much of the new pattern of construction, and the skyline change, is in fact associated with residential rather than office buildings. According to the CLUE database obtained from MCC, the total space and number of dwellings in the CBD has grown 10 times in the last decade. This shift as ushered in by a change in policy. After the mid 1990s, the dual purpose 'office and retail' and 'residential and retail' land use planning categories were created to replace the original single-purpose office use, which was the major trend during the early 1990s. Almost a half of the buildings constructed after the mid 1990s were dual purpose (Table 1). Undoubtedly, the oversupply of office space discussed earlier also paved the way for a shift in the type of building supplied by developers (Tsutsumi 2005). 


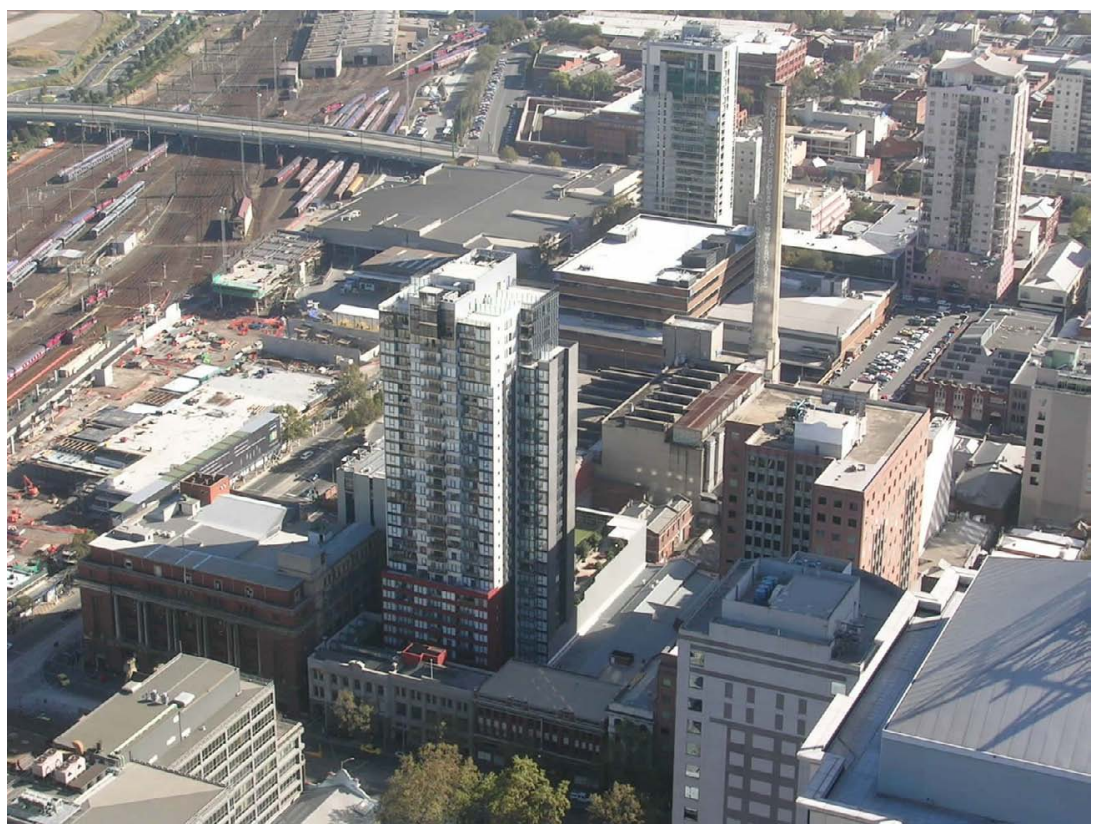

Picture 1 Typical Melbourne architecture

\begin{tabular}{|clll|}
\hline Built Year & Name of Building & Levels & Purposes \\
\hline 1991 & 120 COLLINS STREET & 56 & Office \& Retail \\
\hline 1991 & BOURKE PLACE & 56 & Office \& Retail \\
\hline 1991 & 101 COLLINS STREET & 54 & Office \& Retail \\
\hline 1991 & MELBOURNE CENTRAL TOWER & 51 & Office \& Retail \\
\hline 1991 & 530 COLLINS & 45 & Office \\
\hline 1991 & GATEWAY EXCHANGE & 20 & Office \\
\hline 1991 & GRAND MERCURE HOTEL & 16 & Hotel \\
\hline 1992 & TELECOM BUILDING & 50 & Office \& Retail \\
\hline 1992 & AUSTRALIA ON COLLINS & 16 & Hotel \\
\hline 1993 & ANZ BANK WORLD HEADQUARTERS 43 & Office \\
\hline 1993 & Riverside Plaza & 23 & Office \\
\hline 1996 & PARAMOUNT & 27 & Residential \\
\hline 1997 & CITY GATE TOWER & 19 & Office \& Retail \\
\hline 1998 & COMMONWEALTH LAW COURTS & 20 & Public (Law Courts) \\
\hline 1999 & REPUBLIC TOWER & 36 & Residential \\
\hline 1999 & WESTIN HOTEL & 19 & Hotel \& Residential \\
\hline 2000 & SAVILLE GRAND & 25 & Hotel \& Residential \\
\hline 2001 & DOCKSIDE TOWER & 26 & Residential \\
\hline 2002 & LIBERTY TOWER & 28 & Residential \& Retail \\
\hline 2002 & Medina Apartments & 18 & Residential \& Retail \\
\hline 2003 & City Point & 30 & Residential \\
\hline
\end{tabular}

Table 1 New trend of newer buildings in the CBD of Melbourne CLUE Database, Melbourne City Council 


\section{CHANGING ACTIVITY IN THE CBD}

\section{CHANGE IN EMPLOYMENT AND RESIDENT POPULATION}

According to the CLUE database, the number of employed residents in the Melbourne central city area as of 2004, based on the place of employment, was 206,081, a remarkable increase compared to the 145,465 in the same area in 1992 (Figure 4 and Figure 5). Just as this relatively low level of jobs in 1992 contributed to the office vacancy problem so the growth up to 2004 has restored demand for office space.

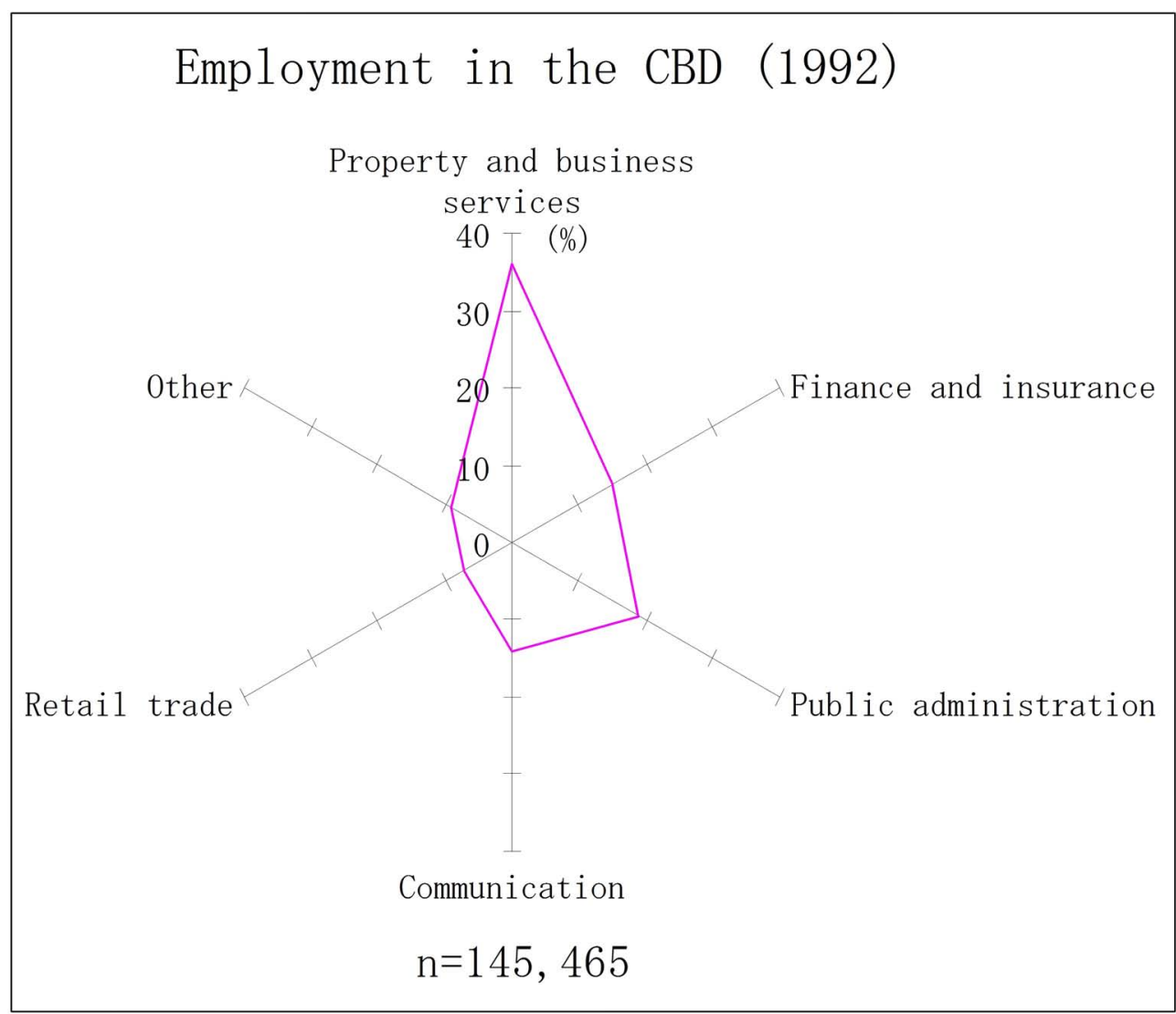

Figure 4 Major category of employment in Melbourne (1992) CLUE Database, Melbourne City Council 


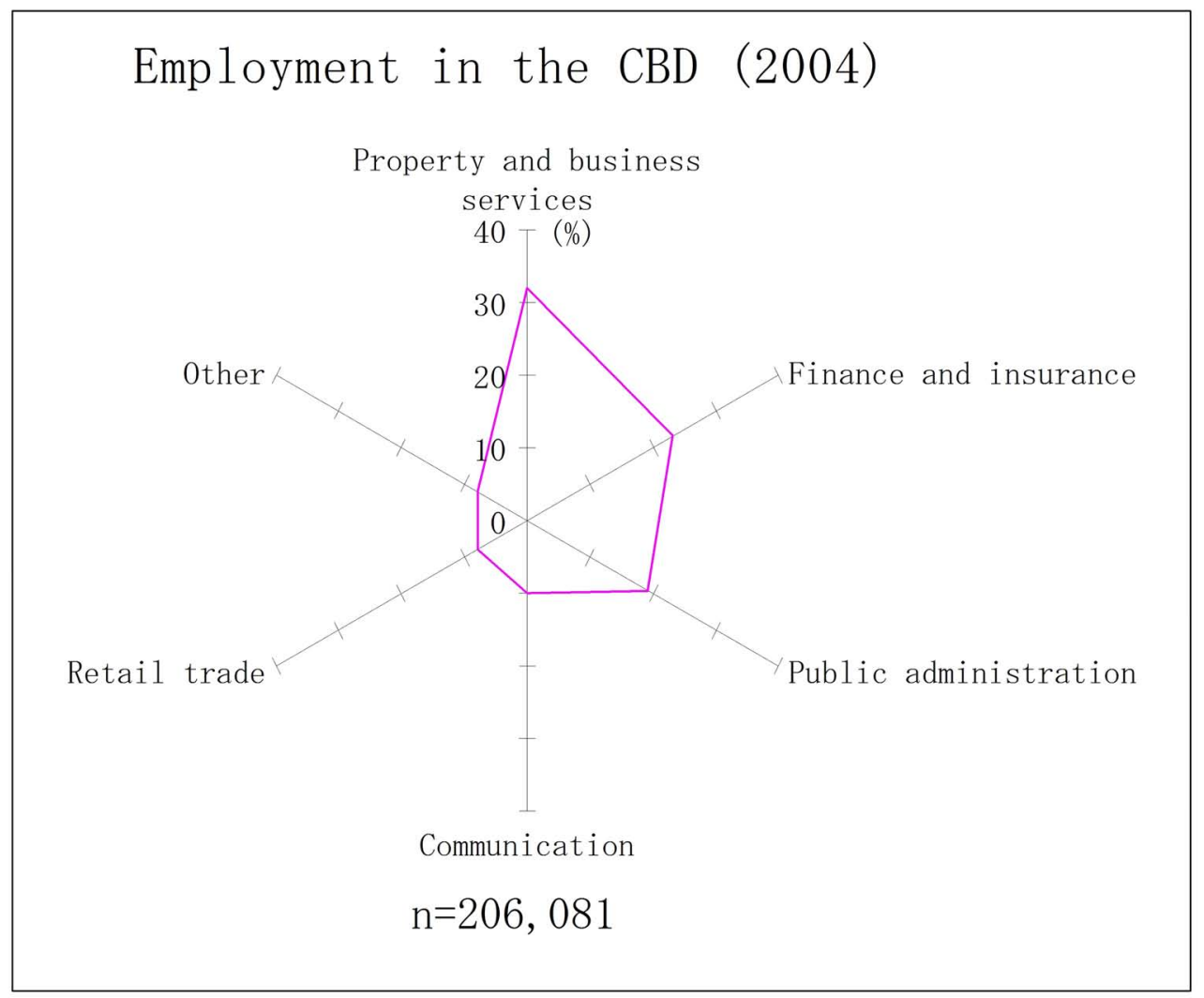

Figure 5 Major category of employment in Melbourne (2004) CLUE Database, Melbourne City Council

The major categories of employment in 1992 were 'property and business services' (36\%), and 'finance and insurance' ( $15 \%)$, which was also very common to other metropolitan areas. In 2004, the two major categories, 'property and business service' (32\%) and 'finance and insurance' $(23 \%)$ were still dominant. $42.4 \%$ of the net increase in employment of 60,616 was due to 'finance and insurance', this category including people who work as IT consultants. Previously however, the dominance of Sydney had been based on categories like finance, insurance, and real estate (abbreviated as FIRE) and the recent remarkable performance of the Melbourne economy, for example, the increase of IT consultant or health related workers, during the period of 1992 to 2004, can be attributed to a growth in these categories. Table 2 and Figure 6 show that 'property and business service', 'finance and insurance' and 'health and community services' are major categories of employment throughout these periods. Among three SLAs in the Melbourne LGA, the categories of 'property and business service' and 'finance and insurance' are most dominant in the CBD. 


\begin{tabular}{|lrrr|}
\hline & $\mathbf{1 9 9 1}$ & $\mathbf{1 9 9 6}$ & $\mathbf{2 0 0 1}$ \\
\hline Manufacturing & $\mathbf{1 , 6 1 4}$ & 1,681 & 2,206 \\
Wholesale Trade & 760 & 1,266 & 1,792 \\
Retail Trade & $\mathbf{1 , 5 6 2}$ & 2,211 & 3,307 \\
Accommodation, Cafes and & 1,382 & 1,625 & 2,446 \\
$\quad$ Restaurants & 860 & 1,342 & 2,098 \\
Finance and Insurance & 1,913 & 3,918 & 6,496 \\
Property and Business Services & 2,237 & 1,970 & 2,609 \\
Health and Community Services & 5,945 & 6,913 & 8,254 \\
Others & $\mathbf{1 6 , 2 7 3}$ & $\mathbf{2 0 , 9 2 6}$ & $\mathbf{2 9 , 2 0 8}$ \\
Total & & & \\
\hline
\end{tabular}

Table 2 Time series employment change in Melbourne (1991-2001) Australian Bureau of Statistics (ABS)

An even more significant shift however has occurred in the residential population. Here we can identify the broad trend of 'inner city living' which in turn has re-shaped the pattern of building construction. Time series census data, which are based on the place of enumeration, are available for 1991, 1996 and 2001 for the Melbourne LGA. According to these data, we can see that recently the CBD experienced growth in population. The rapid increase of people living in the CBD has created growth in sectors like 'retail trade' and 'accommodation, cafes and restaurants' within it. Significantly, the data in table 2 shows that growth in 'accommodation, cafes and restaurants' is found predominantly in the two SLAs on the edge of the CBD.

This new residential growth has been shaped in large part by the construction of buildings for rent. In 2004, people who were either renting or boarding occupied $63 \%$ of apartments in the area, with the remaining $37 \%$ being owner occupied. "Single living in a group or shared household" is currently dominant within the CBD. In the case of renters, this trend is much more apparent. Nearly a half of the total number of rental properties is occupied by such groups. It is possible that this surge in population is associated with the increase in the number of employees involved in the growing sectors discussed earlier, such as finance and insurance, including IT consultants. That link between inner city work and residence would be consistent with the way gentrification has re-shaped the inner parts of big cities in recent years.

However, there is a special new factor in the Melbourne experience. This has been detected in a growing trend toward a multicultural dimension of the resident population observed in the last decade. The proportion of Melbourne people born overseas was over 30 percent, which is slightly higher than the national average (27.4 percent, 2001 census). This has been traced to a rapid rise in the number of international students in the City of Melbourne. O'Connor (2004b) reported the number of international students in Melbourne who go to tertiary institutions (universities) was over 50,000, which was double that of 1996. The increase of international students is very important for the growth of the CBD. The reason is that the students spend a great deal of money in the residential and retail market in the CBD. It is likely that the demand they have created has underpinned many brand-new retail developments and related high-rise housing developments (O'Connor 2004b). At the same time these buildings are not anchored to the old business axis of Collins-Bourke Streets, so help explain the horizontal change in the pattern of construction in the latter 1990s that was detected earlier. 


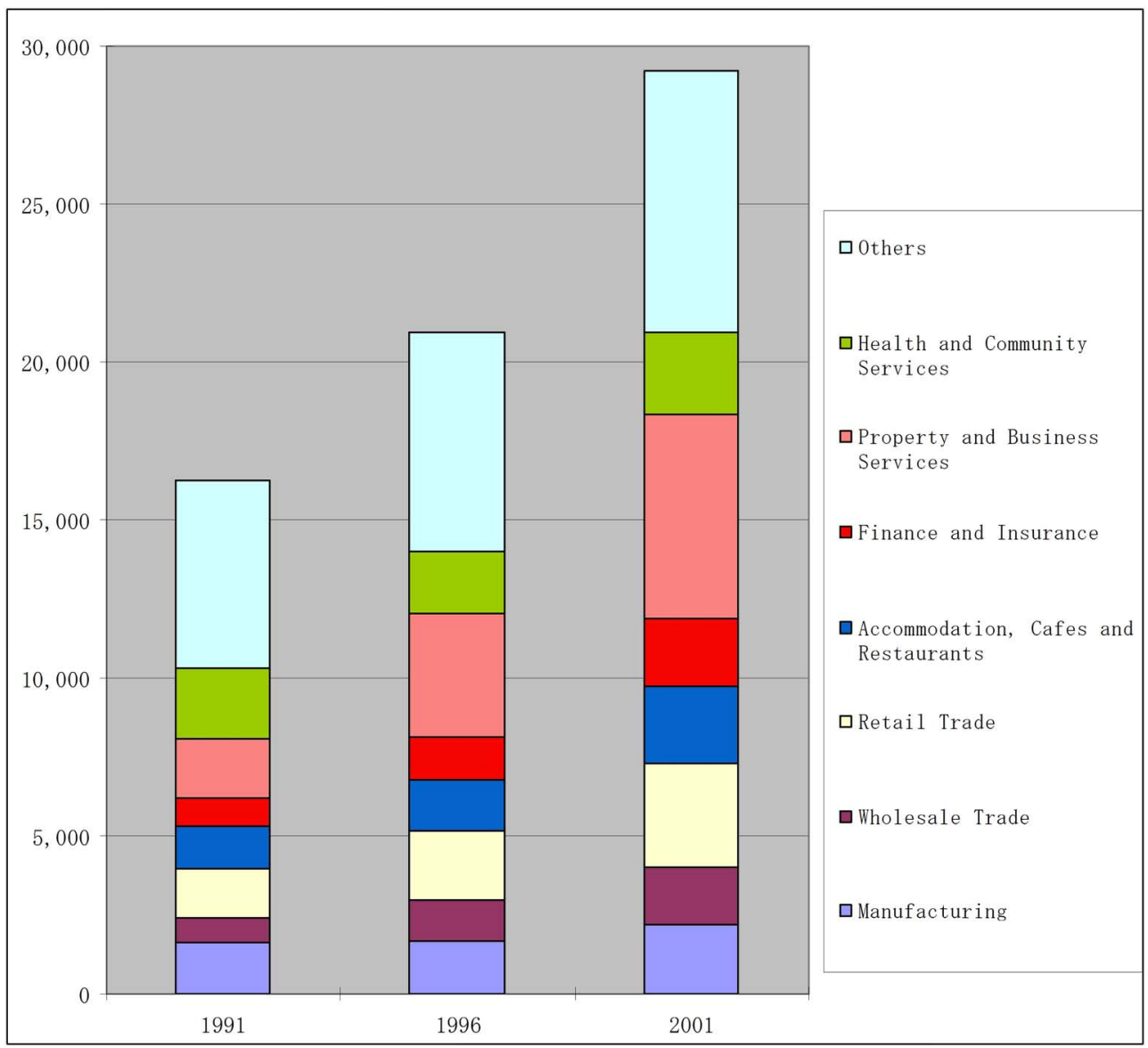

Figure 6 Time series employment change in Melbourne (1991-2001) Australian Bureau of Statistics (ABS)

\section{DISCUSSION - A NEW MODEL FOR CBD CHANGE}

The Melbourne CBD has been subject to a broad array of influences which have re-shaped its building stock. These forces include regional shifts in the location of manufacturing and retail, which freed up space for new buildings, while national shifts in the location of the finance insurance and real estate sector were felt at times in boom-type construction activity, which has been followed by high levels of vacancies in office buildings. That background has provided a distinctive spatial framework, which has been re-shaped by the recent shift toward a local and international population demanding residential buildings. That experience provides the foundation upon which to build a new model of CBD development.

Figure 7 shows a schematic model for the development of the CBD of Melbourne. Until the 1980s, the distribution of each type of urban function was very simple: offices were located along Collins Street, retail was located along Swanston Street. Manufacturing activity was still dominant in the peripheral area. In the 1990s, both horizontal and vertical expansions of offices were seen. 
A combination of office and retail projects has maintained the vertical dimension, while residential redevelopments contribute to the new horizontal dimension. It is this unique feature that defines contemporary from redundant within Melbourne. Consistently, as certain functions within the CBD became redundant and were discarded, functional rebirth occurred. As retail function waned, gentrification bloomed. Similarly, as gentrification lost its momentum, existing structures were re-functioned, and new high-rise residential developments rose to cater for the influx of international students.

1980s

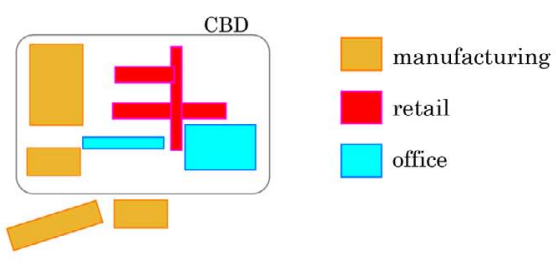

1990s

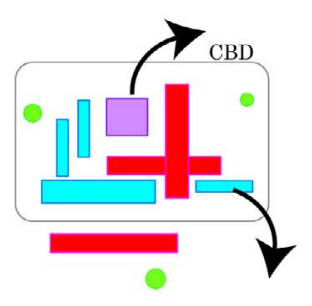

residential

retail \& office complex

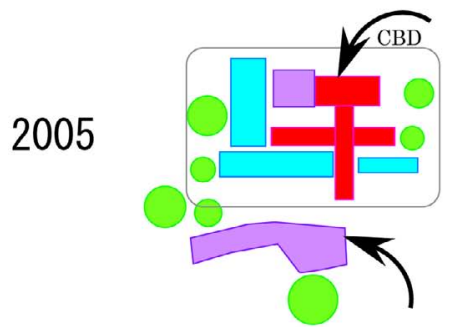

Figure 7 A schematic model for the changing role of Melbourne's CBD

\section{CONCLUDING REMARKS}

The spatial-temporal analysis of buildings in the Melbourne CBD has proved a powerful way of identifying the impact of change in the functions in the CBD of Melbourne. While Sydney has developed a higher rank in terms of global function and international investment, the Melbourne CBD has adjusted its function and built form to continue a significant role in business but more recently in high-rise residential construction especially for international students. This dynamism and diversity gives the city much of its charm and power, and attracts many newcomers to the city. 


\section{ACKNOWLEDGEMENTS}

The first author owes endless gratitude to many people who gladly supported him in writing this paper. Special appreciation goes to Associate Professor Dr. Ray Wyatt and other scholars of the SAGES, the University of Melbourne, for their kind advice and many invaluable comments during his stay from March to June, 2005.

The first author is also grateful to Dr. Steven Phillips, Dr. Thomas Waldichuk and Anthony Roberts BSc (hons) for their useful comments during the preparation of the English manuscript.

The abstract of this article was presented at the 2005 IGU commission on Monitoring Cities of Tomorrow held in Tokyo. The research for this paper was partially supported by a Grant-inAid for Scientific Research from the Japan Society for the Promotion of Science (2002-2005, No. 14780047).

\section{REFERENCES}

Brown-May; Shurlee S. 2005. The Encyclopedia of Melbourne. Melbourne: Cambridge University Press.

Goodman, A. 1983. Melbourne's City Centre 1972-1982. Working Paper 15. Melbourne: Department of Geography, Monash University. 97p.

Fothergill, N.C. 1987. Metropolitan office development. Working Paper 3. Melbourne: Ministry for Planning and Environment. Policy and Strategic Planning Branch.

Hajdu, J. 1994. 'Recent Cycles of Foreign Property Investment in Central Sydney and Melbourne'. Urban Geography 15 (3): 246-257.

Maher, C 1988. 'Process and response in contemporary urban development: Melbourne in the 1980s'. Australian Geographer 19: 162-181.

O'Connor, K. 2002. 'Rethinking Globalisation and Urban Development: The Fortunes of Second -ranked Cities'. Australasian Journal of Regional Studies 8 (3) 35-48.

O'Connor, K. 2004a. The Inner City Apartment Market: Review and Prospect. Melbourne: The Property Council of Australia, Victorian Division.

O'Connor, K. 2004b. International Students and Global Cities. Research Bulletin 161. Leicestershire: Global and World City Project. Department of Geography, University of Loughborough.

Tsutsumi, J. 2005. 'Urban restructuring process in the CBD of Melbourne, Australia - Is this development a kind of globalization in a particular way?' In Cities in Global Perspective: Diversity and Transition, edited by Murayama, Yuji; Du, Guoquing. Tokyo: College of Tourism, Rikkyo University with IGU Urban Commission on Monitoring Cities of Tomorrow. pp. 308-312.

Tsutsumi, J.; O'Connor, K. 2005. 'International Students and the Changing Character of the Inner Area of a City: A Case Study of Melbourne.' State of Australian Cities: National Conference. Brisbane.

Cite this article as: Tsutsumi, Jun; 0 'Connor, Kevin. 2006. 'Time series analysis of the skyline and employment changes in the CBD of Melbourne'. Applied GIS 2 (2). pp. 8.1-8.12. D0I: 10.2104/ag060008. 